\title{
ORIGINAL ARTIGLE
}

\section{The role of fungus Beauveria bassiana in reducing the number of Pissodes castaneus (Col., Curculionidae) in young forests}

\author{
Iwona Skrzecz $z^{1} \bowtie$, Elżbieta Popowska-Nowak ${ }^{2}$, Robert Wolski ${ }^{1}$, Alicja Sowińska ${ }^{1}$, \\ Tomasz Jabłoński ${ }^{1}$, Elżbieta Pezowicz ${ }^{3}$, Dorota Tumialis ${ }^{3}$, Iwona Przewłoka ${ }^{3}$ \\ ${ }^{1}$ Forest Research Institute, Department of Forest Protection, Sękocin Stary, Braci Leśnej 3, 05-090 Raszyn, Poland, \\ e-mail: i.skrzecz@ibles.waw.pl \\ ${ }^{2}$ University of Kardynal Stefan Wyszynski, Faculty of Biology and Environmental Sciences, Wóycickiego 1/3, \\ 01-938 Warsaw, Poland \\ ${ }^{3}$ Warsaw University of Life Sciences - SGGW, Faculty of Animal Sciences, Department of Animal Environment Biology, \\ Ciszewskiego 8, 02-786 Warsaw, Poland
}

\section{Abstract}

Small banded pine weevil Pissodes castaneus is one of the most dangerous pests of Pinus sylvestris plantations and thickets. The lack of effective and environmentally safe methods of limiting the number of the pest justified to undertake the studies aimed at the laboratory and field evaluation of biological activity of entomopathogenic fungus Beauveria bassiana used to reduce the numbers of small banded pine weevil.

In laboratory, the beetles were reared on the sections of fresh Scots pine twigs that were treated with five suspensions containing from $1 \times 10^{4}$ to $1 \times 10^{8}$ conidia of $B$. bassiana in $1 \mathrm{ml}$. During the 3 -week rearing, insect mortality was determined and median lethal concentration $\mathrm{LC}_{50}$ was calculated. The field treatments consisted of spraying 4-year-old $P$. sylvestris trees with two formulations of fungus containing $1 \times 10^{8}$ conidia ml $^{-1}$ of suspension. Treatments consisted of spraying 4-year-old $P$. sylvestris trees with two fungus formulations containing $1 \times 10^{8}$ conidia $\mathrm{ml}^{-1}$.

High insecticidal activity of $B$. bassiana was found because the pathogen caused the death of $14-94 \%$ of $P$. castaneus beetles, $\mathrm{LC}_{50}=6.51 \times 10^{5}$ conidia $\mathrm{ml}^{-1}$. Field treatments did not result in the reduction of plant damage caused by small banded pine weevil; therefore, the spraying of trees with $B$. bassiana cannot be recommended to protect the young stands of $P$. sylvestris against pest.

\section{KEY WORDS}

Beauveria bassiana, Pissodes castaneus, Pinus sylvestris, biological control 


\section{INTRODUCTION}

In Poland, protection of young stands against harmful insects is one of the current problems in forestry. It includes the protection of restock areas against small banded pine weevil Pissodes castaneus De Geer., which prefers single-species plantations and thickets of Scots pine (Pinus sylvestris L.) weakened by biotic factors, mainly pathogenic fungi and deer, as well as abiotic factors including abnormally developed root system, drought, hail and fire.

Small banded pine weevil commonly occurs in Europe, the Asian part of Russia, Turkey and North Africa and, in 2001, was dragged to South America (Panzavolta and Tiberi 2010; Lede et al. 2010; CABI 2011). In Poland, it occurs within Scots pine (Kapuściński 1950). The beetles leave the wintering places in the first half of April and they start to feed mainly on buds and last year's young shoots of pines, which with their mass occurrence can lead to a weakening of trees. Most often in May, the females lay eggs around the root collar and on lower parts of pine stems. For the trees, the larvae are more harmful than the beetles because they feed the tunnels under the bark, causing dieback of infested trees (Panzavolta and Tiberi 2010; Kapuściński 1950). In Europe, the species have not been causing an economic problem until the beginning of current century, when the area of its occurrence in Europe increased, including Poland to nearly 8,000 ha per year, leading to the destruction of affected crops (Panzavolta and Tiberi 2010; Brodziak 2011; Jabłoński et al. 2016).

In the available literature, there is a little information on how to prevent damage caused by $P$. castaneus in young stands. The only one method used in practice to reduce the population of this species is based on removing and destroying the trees inhabited by weevil. The lack of insecticides registered for pest control eliminates the use of chemical methods during mass occurrence of $P$. castaneus in young stands.

In Poland, for the past 50 years, the small banded pine weevil has not been studying because they were not dangerous from economical point of view. The lack of effective and, at the same time, environmentally safe methods was the reason for taking the studies pointed at the reducing the number of pests in forest plantations and thickets with the use of entomopathogenic fungus Beauveria bassiana (Bals.-Criv.) Vuill. The scope of work included laboratory assessment of biological activity of $B$. bassiana and field treatments determining the possibility of using the pathogen to limit the number of $P$. castaneus in restock areas.

\section{MAterial AND MEthodS}

\section{Laboratory assessment of biological activity of B. bassiana}

The beetles used in bioassay were collected in April 2011 from the 3- to 5-year-old Scots pine plantations located in south-east Poland (Forest District Mielec: $\left.50^{\circ} 21^{\prime} 48.8^{\prime \prime} \mathrm{N} 21^{\circ} 36^{\prime} 40.4^{\prime \prime} \mathrm{E}\right)$. Following the transfer to the laboratory, the beetles were placed in glass containers and kept fasting for $24 \mathrm{~h}$.

The isolate of B. bassiana (original collection number WG, isolated from a soil in South part of Poland, Forestry District Wegierska Górka: 49³6'30.0"N, $\left.19^{\circ} 07^{\prime} 00.1^{\prime \prime} \mathrm{E}\right)$ was derived from the collection of the Department of Biology and Environmental Sciences of Cardinal Stefan Wyszynski University in Warsaw, Poland. The conidia was obtained from the fungus culture on agar slants. Next they were inoculated on solid media in culture flasks Roux. After 14 days, the conidia were collected and suspended in $0.02 \%$ Triton X-100. Five concentrations of $B$. bassiana containing $1 \times 10^{4}$, $1 \times 10^{5}, 1 \times 10^{6}, 1 \times 10^{7}, 1 \times 10^{8}$ conidia in $1 \mathrm{ml}$ were prepared by serial dilutions and the concentrations of conidia were determined in Thoma cell counting chamber.

The $P$. castaneus beetles were reared on food treated with the suspension of $B$. bassiana conidia. One section of fresh pine twig with a length of $2 \mathrm{~cm}$ and a diameter of about $1 \mathrm{~cm}$ and one beetle were placed in each sterile Petri dish (10 cm diameter) with filter paper on the bottom. A volume of $200 \mu 1$ of conidia suspensions was delivered with micropipette to inoculate the bark of twig. Rearing of beetles on the twig sections treated with $200 \mu$ of $0.02 \%$ Triton X-100 was a comparative variant of experiment and control-untreated twig sections were treated with $200 \mu$ of distilled water. After $24 \mathrm{~h}$, in all variants, the treated twigs were replaced with untreated ones. In the next days of experiment, the twig sections were replaced for every $72 \mathrm{~h}$.

Altogether seven variants of experiments were established (five suspensions of fungus, comparative and control-untreated variants); in each, 40 beetles were 
tested, a total of 280 insects. The experiment was conducted during 21 days at $22^{\circ} \mathrm{C}, 70 \% \mathrm{RH}$ and a photoperiod of 16:8 (L:D) h. Insect mortality was estimated each day, and based on the results, $\mathrm{LC}_{50}$ and $\mathrm{LC}_{90}$ (concentration required to cause, respectively, 50\% and $90 \%$ mortality) was calculated using probit regression analysis of fungus concentrations that have been logarithmically transformed according to the Finney method (1962) using POLO PC program, version 2.0 (LeOra Software, USA).

In the case of dead individuals in control-untreated variant, the beetle mortality was calculated using $\mathrm{Ab}$ bott formula, taking into account the natural mortality of the tested insects. Dead beetles were individually placed in a sterile Petri dishes (diameter $6 \mathrm{~cm}$ ) with moistened filter paper, and after 48-36 h, they were diagnosed to document mycelium of $B$. bassiana on the basis of morphological characteristic.

\section{Field spraying with B. bassiana}

Field treatments were performed in 2012 in central Poland (Forest District Celestynów: $52^{\circ} 04^{\prime} 50.6^{\prime \prime} \mathrm{N}$; $21^{\circ} 20^{\prime} 54.0^{\prime \prime} \mathrm{E}$ ) in 4-year-old Scots pine plantations with an area of 3 ha in which the small banded pine weevil beetles were feeding on trees in April of the same year. In experimental plantations, more than $90 \%$ of trees were weakened by fungi of the genus Lophodermium. The treatment was performed in the second half of April, during the period of beetle feeding and egg laying by females on the lower parts of tree stems.

In the experiment 2 , isolates of $B$. bassiana were used: the first one tested in laboratory bioassay and the second - comparative isolate - formulated as biopreparation BoVeril (producer Bioved $2005 \mathrm{Kft}$, Slovakia) in the form of powder containing $5 \times 10^{8}$ conidia $\mathrm{g}^{-1}$ (isolate original collection number BB1). Both isolates were used in the form of water suspensions containing $1 \times 10^{8}$ conidia $\mathrm{ml}^{-1}$. The suspensions were prepared $24 \mathrm{~h}$ before treatment and stored at $5^{\circ} \mathrm{C}$ till the application.

The treatments consisted of spraying the parts of the stems from the root collars to a height of about 20 $\mathrm{cm}$, where the females lay eggs and the larvae hatch. The suspensions were applied with the use of garden sprayer, at $3.5 \mathrm{Ba}$ and a dose of approximately $100 \mathrm{ml}$ of preparation per tree. The comparative control consisted of trees sprayed with the same dose of water. In each variant of the experiment (two suspensions of fungus and untreated), 100 trees were sprayed in the spatial distribution of 20 trees in 5 rows (repetitions).

The efficacy of treatments was estimated after 6 months (the second half of September) based on the numbers of trees with symptoms of colonisation by $P$. castaneus: yellow needles, upper shoots hanging down and resin leaks on the stems. These trees were taken out and stripped in the laboratory, and the larvae located on the stems from the root collar to a height of $20 \mathrm{~cm}$ were counted. The numbers of seedlings colonised by the pest as well as the numbers of its larvae in all variants of experiment were compared with the Kruskal-Wallis non-parametric analysis of variance. Differences were considered significant in the post-hoc test when the probability value was lower than the adopted significance level $\mathrm{p} \leq 0.05$. Calculations were analysed using Statistica v.10 (StatSoft ${ }^{\circledR}$ Inc. USA) package.

\section{Results}

\section{Biological activity of $B$. bassiana in laboratory conditions}

Within 3 weeks, a systematic increase in mortality of beetles feeding on twigs treated with $B$. bassiana was observed (Fig. 1). This increase was directly proportional to the concentration of conidia and was the highest in the group of beetles treated with concentrations of $1 \times 10^{7}$ to $1 \times 10^{8}$ conidia $\mathrm{ml}^{-1}$. The mortality increased to more than $50 \%$ and $80 \%$ of insects after 2 and 3 weeks, respectively.

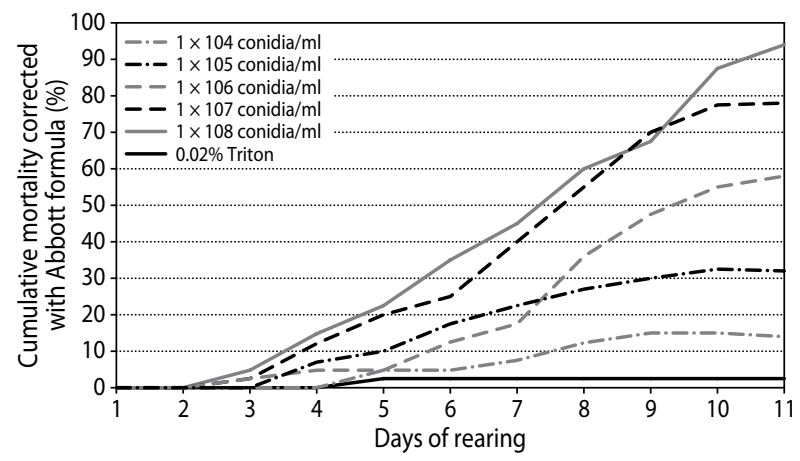

Figure 1. Mortality of Pissodes castaneus beetles reared on Pinus sylvestris branches treated with Beauveria bassiana 
After the first week, the mortality of beetles feeding on twigs treated with lower concentrations of the pathogen $\left(1 \times 10^{4}\right.$ to $1 \times 10^{6}$ conidia $\left.\mathrm{ml}^{-1}\right)$ did not exceed $5 \%$. More dynamic increase in insect mortality in these variants was stated in the following weeks: up to $12-36 \%$ after 14 days and up to $15-58 \%$ in the last day of the experiment.

Mortality of insects on pine twigs treated with $0.02 \%$ Triton and untreated ones increased up to $2 \%$ in the second week and remained constant to the end of the experiment.

The mortality of insects having contact with the twigs inoculated with fungus was caused by B. bassia$n a$, whilst the cause of death of insects in comparative and control variants was unknown.

The results allowed to calculate the lethal concentration of conidia causing $50 \%\left(\mathrm{LC}_{50}\right)$ and $90 \%\left(\mathrm{LC}_{90}\right)$ mortality of tested beetles (Tab. 1).

Table 1. $\mathrm{LC}_{50}$ and $\mathrm{LC}_{90}$ (conidia $\mathrm{ml}^{-1}$ ) for Beauveria bassiana used against Pissodes castaneus

\begin{tabular}{|l|c|}
\hline \multicolumn{1}{|c|}{ LC $_{50}$} & $6.51 \times 10^{5}$ \\
\hline $95 \%$ limits & $2.51 \times 10^{5}-1.45 \times 10^{6}$ \\
\hline $\mathrm{LC}_{90}$ & $7.86 \times 10^{7}$ \\
\hline $95 \%$ limits & $3.04 \times 10^{7}-8.11 \times 10^{8}$ \\
\hline slope $\pm \mathrm{SD}$ & $0.705 \pm 0.100$ \\
\hline$\chi^{2}$ & 0.128 \\
\hline $\mathrm{df}$ & 3 \\
\hline $\mathrm{H}$ & 0.04 \\
\hline
\end{tabular}

\section{Efficacy of B. bassiana in field treatments}

The evaluation of the field treatments showed no statistical differences between the mortality of $P$. sylvestris trees in all experimental variants $(H=5.473 ; p=0.0748)$ (Tab. 2). On the plots treated with B. bassiana, a colonisation of $13 \%$ and $11 \%$ of trees sprayed with isolates, respectively, WG and $\mathrm{BB} 1$, as well as $14 \%$ of untreated trees, was found.

Only living larvae of $P$. castaneus were found in the stems of observed trees. There were no statistically significant differences between the numbers of larvae developing in the treated and untreated fungus ( $H=0.1305 ; p=0.9368)$ (Tab. 2). In all the variants of treatment, there were from 7 to 16 larvae in the lower parts of stems with a length of $20 \mathrm{~cm}$.
Table 2. Colonization of trees treated with Beauveria bassiana by Pissodes castaneus

\begin{tabular}{|l|c|c|}
\hline $\begin{array}{c}\text { Fungus } \\
\text { strain }\end{array}$ & $\begin{array}{c}\text { Mean ( } \pm \text { st. dev. }) \\
\text { numbers of dead } \\
\text { trees }\end{array}$ & $\begin{array}{c}\text { Mean ( } \pm \text { st. dev.) numbers } \\
\text { of larvae found on the stem } \\
\text { section }(20 \text { cm length })\end{array}$ \\
\hline WG & $10.8 \pm 2.1$ & $9.9 \pm 2.5$ \\
\hline BB1 & $8.6 \pm 1.9$ & $10.6 \pm 1.6$ \\
\hline $\begin{array}{l}\text { control- } \\
\text { untreated }\end{array}$ & $11.6 \pm 1.8$ & $12.1 \pm 2.3$ \\
\hline
\end{tabular}

\section{Discussion}

Research on the use of natural enemies to limit the number of Pissodes weevils have been concentrating mainly on the biology of parasitoids and also included a discussion on the possibility of their use in the form of introduction to the areas of pest increased occurrence (Kenis and Mills 1994; Kenis et al. 2004). So far, the papers published by Alauzet $(1987,1990)$ and Kenis et al. (1994, 1996, 2004) contain most information on the parasitoids of $P$. castaneus. Whilst little information concerns the pathogens of Pissodes weevils, mainly white pine weevil Pissodes strobi (Peck), which, especially in North America, is a dangerous pest of white pine (Pinus strobus L.) and Norway spruce [Picea abies (L.) H. Karst] (Alfaro et al. 1995). Streett et al. (1975) described the morphology of microsporidia Nosema sp. isolated from death and alive larvae of $P$. strobi from the population occurring in Maryland, USA. At the same time, they suggested the use of these microorganisms to reduce the number of pest. There is also the lack of studies to use the entomopathogenic fungi against Pissodes weevils. Only Trudel et al. (2007) made laboratory attempts to assess the potential use of $B$. bassiana to limit the population of $P$. strobi. Thus, the presented results of experiments on the use of $B$. bassiana in the forms of prepared in the laboratory conidia suspensions and commercially available bioproduct 'BoVeril' to reduce $P$. castaneus population are the first information of this type.

The laboratory results showed a mortality of over $90 \%$ of $P$. castaneus beetles feeding on twigs treated with different concentrations of $B$. bassiana conidia. Similar results were obtained by Trudel et al. (2007), who observed nearly $90 \%$ mortality of $P$. strobi beetles feeding on the sections of $P$. strobus twigs treated with Canadian isolates of B. bassiana. Comparison of $\mathrm{LC}_{50}$ 
obtained in presented results and those found in Trudel's et al.(2007) studies pointed at the higher activity of Polish isolate. The higher activity of $B$. bassiana in laboratory conditions was confirmed in the studies pointed at its use in limiting the number of the large pine weevil Hylobius abietis L. - another curculionids feeding on young coniferous trees. Wegensteiner and Führer (1988), who analysed the mortality of $H$. abietis beetles infected by the fungus in laboratory conditions found $100 \%$ mortality of insects feeding on a bark of Norway spruce treated with $1.17 \times 10^{8}$ conidia $\mathrm{cm}^{-2}$ bark. Similar tests were made by Ansari and Butt (2012), who observed $100 \%$ mortality of $H$. abietis beetles during 3 weeks after infection with $B$. bassiana at the concentration $1 \times 10^{8}$ conidia $\mathrm{ml}^{-1}$.

Despite the high activity of $B$. bassiana in the laboratory, the results of field trials showed no effect of fungus treatment on the infestation of Scots pines by $P$. $\mathrm{Ca}$ staneus. The lack of similar field experiments described in the literature makes the discussion of obtained results difficult. Most of the field trials limiting the number of pest forest insects with $B$. bassiana was related to species such as $H$. abietis and spruce bark beetle Ips typographus $\mathrm{L}$. The results of these tests confirmed the low efficiency of pathogen in the protection of forest against pest insects. Wegensteiner and Führer (1988) paid attention to very low mortality of $H$. abietis beetles attracted to the spruce bark treated with B. bassiana. Williams et al. (2013) tried to reduce the numbers of H. abietis larvae developing in the stumps through the application of $B$. bassiana together with entomopathogenic nematodes (Sterneinema carpocapsae and Heterorhabditis downes) on these stumps. The results showed a higher effectiveness of nematodes (up to $50 \%$ mortality of larvae) compared to very low efficacy of fungus (up to $3.5 \%$ mortality of larvae).

Experiments on the use of $B$. bassiana in relation to the spruce bark beetle were conducted in Poland since the 1960 of last century, but the field application of the pathogen did not give satisfactory results (Bałazy 1962; Cichońska and Świeżyńska 1993; Głowacka and Świeżyńska 1993; Malinowski 2011). The studies carried out by Grodzki and Kosibowicz (2015) confirmed the low efficacy of $B$. bassiana applied in powder form in pheromone traps to capture and thereafter release fungus-infected bark beetles to the forest environment. Also direct spraying or dusting of lying trap logs made from
$P$. abies did not have any effect on spruce infestation by $I$. typographus, its reproduction success and development or natural enemies inside the bark. Whilst in Slovakia, spraying of standing trees infested by $I$. $t y$ pographus leaded to $28 \%$ mortality of pest caused by pathogen (Jakuš and Blaženec 2011).

Thus, the literature data and the results of field experiments presented in this publication do not recommend the use of $B$. bassiana in forest protection against small banded pine weevil. However, promising results of laboratory experiments may provide a basis for further research to achieve greater effectiveness in the field treatments.

\section{Acknowledgements}

The experiments were financed by General Directorate of State Forests in Poland, project no. BLP-362.

\section{References}

Alauzet C. 1987. Bioecology of Eubazus semirugosus, Coeloides abdominalis and C. sordidator (Hym.: Braconidae) parasites of Pissodes notatus (Col.: Curculionidae) in southern France. Entomophaga, 32 (1), 39-47.

Alauzet C. 1990. Population dynamics of the pine pest Pissodes notatus F. (Col.: Curculionidae). 2. The role of parasitism. Entomophaga, 35 (1), 119-126.

Alfaro R.I., Borden J.H., Fraser R.G., Yanchuk A. 1995. The white pine weevil in British Columbia: Basis for an integrated pest management system. Forestry Chronicle, 71, 66-73.

Ansari M.A., Butt T.M. 2012. Susceptibility of different developmental stages of large pine weevil Hylobius abietis (Coleoptera: Curculionidae) to entomopathogenic fungi and effect of fungal infection to adult weevils by formulation and application methods. Journal of Invertebrate Pathology, 111 (1), 33-40.

Bałazy S. 1962. Observations on the occurrence of certain insecticidal fungi from the group of Fungi Imperfecti on forest insects (in Polish). Polskie Pismo Entomologiczne, Seria B, 3/4 (27/28), 149-164.

Brodziak $Ł$. 2011. The threat of the pine plantation and saplings by small banded pine weevil in the area 
of RDSFs Lublin and Radom (in Polish). Postępy Techniki w Leśnictwie, 116, 46-51.

CABI. 2011. Pissodes castaneus (small banded pine weevil). Invasive Species Compendium, Commonwealth Agricultural Bureau International (CABI), Wallingford, UK. http://www.cabi.org/isc/datasheet $/ 41485$.

Cichońska A., Świeżyńska H. 1993. Attempts to use fungal bioproducts to reduce the population of certain harmful forest insects (in Polish). Prace IBL, Seria A, 761/769, 137-144.

Finney D.J. 1962. Probit Analysis. Cambridge University Press, Cambridge, England,

Głowacka B., Świeżyńska H. 1993. Entomopathogenic fungi occurring in forest insects (in Polish). Prace IBL, Seria A, 761/769, 117-136.

Grodzki W., Kosibowicz M. 2015. An attempt to use the fungus Beauveria bassiana (Bals.) Vuill. in forest protection against the bark beetle Ips typographus (L.) in the field. Forest Research Papers, 76 (1), 5-17.

Jabłoński T. et al. 2016. The short-term forecast of major pests and forest trees diseases occurrence in Poland in 2016. Forest Research Institute, Analyses and Reports No. 18 (in Polish).

Jakuš R., Blaženec M. 2011. Treatment of bark beetle attacked trees with entomopathogenic fungus Beauveria bassiana (Balsamo) Vuillemin. Folia Forestalia Polonica, Series A - Forestry, 53 (2), 150-155.

Kapuściński S. 1950. Weevils (in Polish). PWRiL, Warsaw, Poland.

Kenis M., Mills N.J. 1994. Parasitoids of European species of the genus Pissodes (Col: Curculionidae) and their potential for the biological control of Pissodes strobi (Peck) in Canada. Biological Control, 4, 14-21.

Kenis M., Hulme M.A., Mills N.J. 1996. Comparative developmental biology of populations of three $\mathrm{Eu}-$ ropean and one North American Eubazus spp. (Hy- menoptera: Braconidae), parasitoids of Pissodes spp. weevils (Coleoptera: Curculionidae). Bulletin of Entomological Research, 86, 78-83.

Kenis M., Wegensteiner R., Griffin Ch. 2004. Parasitoids, predators, nematodes and pathogens associated with bark weevil pest. In: Bark and wood boring insects in Living Trees in Europe, a synthesis (eds.: F. Lieutier, K.R. Day, J.-C. Grégoire, H.F. Evans). Springer, Berlin, 395-414.

Lede E.T., Filho W.R., Penteado S.R.C., Zaleski S.M. 2010. Pissodes castaneus (De Geer, 1775) (Coleoptera, Curculionidae), the bark pine weevil: a pest or a biological indicator? USDA Research Forum on Invasive Species, GTR-NRS-P-75, 95.

Malinowski H. 2011. Activity of entomopathogenic fungi against forest insects feeding on leaves, bark and cambium (in Polish). Sylwan, 155 (3), 188-194.

Panzavolta T., Tiberi R. 2010. Observations on the life cycle of Pissodes castaneus in central Italy. Bulletin of Insectology, 63 (1), 45-50.

Streett D.A., Sprague V., Harman D.M. 1975. Brief study of microsporidian pathogens in the white pine weevil Pissodes strobi. Chesapeake Science, 16 (1), 32-38.

Trudel R., Lavalle'e C., Guertin C., Cote C., Todorova S.I., Alfaro R., Kope H. 2007. Potential of Beauveria bassiana (Hyphomycetes: Moniliales) for controlling the white pine weevil, Pissodes strobi (Col., Curculionidae). Journal of Applied Entomology, 131 (2), 90-97.

Wegensteiner R., Führer E. 1988. Zur wirksamkeit von Beauveria bassiana (Bals.) Vuill. Gegen Hylobius abietis L. (Col. Curculionidae). Entomophaga, 33 (30), 339-348.

Williams C.D., Dillon A.B., Harvey Ch.D., Hennessy R., Namara L.Mc., Griffin Ch.T. 2013. Control of a major pest of forestry, Hylobius abietis, with entomopathogenic nematodes and fungi using eradicant and prophylactic strategies. Forest Ecology and Management, 305, 2012-2022. 